\title{
Analisis Pengaruh Nilai Peak Ground Acceleration (PGA) Terhadap Story Shear Bangunan Bertingkat
}

\section{Analysis of the Effect of Peak Ground Acceleration (PGA) Value on Standing Shear Buildings Story}

\author{
Ahmad Hamidi \\ Jurusan Teknik Sipil Sekolah Tinggi Teknologi Pekanbaru \\ Telp.0761.61815 Fax.0761-61815 Email: hamidi4407@gmail.com
}

\begin{abstract}
This study aims to analyze and examine the effect of peak land acceleration value (PGA) on shear story using dynamic method of response spectrum. The PGA value and the spectrum response used are the spectrum responses issued by the PU ministry. The review is soft land in the citys in Riau. The results showed that the higher the story shear value, the higher the PGA value in each region. The areas with the highest inner and PGA grades are Pasir Pangarian (Rohul) and the lowest is Kota Selat Panjang (Meranti District). This is because the area of Rohul Regency is an area close to West Sumatera Province that has a high enough earthquake intensity when compared with Meranti Regency which is a coastal area located on the lower plains.
\end{abstract}

Keywords: Story Shear, Respons Spektrum, Peak Ground Acceleration

\section{PENDAHULUAN}

Indonesia merupakan Negara Maritim yang memiliki lebih dari 17.000 pulau dan terletak pada pertemuan tiga lempeng tektonik utama dunia yang selalu bergerak satu sama lainnya. Ketiga lempeng tektonik tersebut adalah lempeng Australia, lempeng Eurasia dan lempeng Pasifik. Menurut Pirwanti (2016), gempa adalah peristiwa bergetarnya bumi akibat pelepasan energi dalam bumi secara tibatiba. Gempa yang terjadi sering kali merusak bangunan-bangunan yang berada disekitar lokasi pusat gempa. Bangunan yang memiliki resiko paling besar terhadap gempa adalah bangunan bertingkat yang memiliki banyak aktifitas manusia di dalamnya dan akan mengakibatkan banyaknya korban jiwa.

PGA merupakan nilai percepatan getaran tanah terbesar (peak grond acceleration) yang pernah terjadi pada suatu daerah yang diakibatkan oleh gempa bumi. Semakin besar nilai PGA yang pernah terjadi maka juga akan semakin besar tingkat resiko gempa bumi yang terjadi pada suatu daerah.
Besarnya frekuensi getaran tanah akan menggambarkan kondisi fisik dari tanah/batuan pada daerah tertentu. Sebagai contoh tanah lunak akan mempunyai periode getaran yang panjang sehingga akan memiliki resiko lebih tinggi saat terjadinya gempa bumi. Tingkat kerusakan yang akan terjadi pada suatu bangunan tergantung dari kekuatan bangunan tersebut, kondisi geologi dan percepatan tanah di lokasi bangunan. Faktor yang merupakan sumber kerusakan dinyatakan dalam parameter percepatan tanah sehingga data PGA pada suatu lokasi bangunan akan menjadi sangat penting untuk menggambarkan tingkat bahaya gempa bumi dan nilai PGA, pada masing-masing daerah akan memiliki nilai yang berbeda. Tanah lunak memiliki kompresibilitas yang tinggi, shear resistance yang rendah sehingga CBR relative rendah (Firdaus, 2010).

Kondisi Indonesia yang berada pada wilayah dengan intensitas gempa yang cukup tinggi membuat bangunan akan menjadi lebih rentan roboh dan banyaknya terjadi korban jiwa. Salah satu pengaruh 
gempa yang akan memberikan efek pada bangunan adalah base shear.

Tujuan dari penelitian ini adalah untuk mendapatkan hasil pengaruh nilai PGA terhadap story shear bangunan bertingkat.

Permasalahan yang akan dibahas adalah analisis mengenai seberapa besar pengaruh nilai percepatan tanah puncak (PGA) terhadap bangunan bertingkat dengan menggunakan metode dinamik respon spektrum.

Penelitian ini memiliki batasan masalahnya antara lain :

a. Penelitian dilakukan dengan menggunakan sofware elemen hingga.

b. Besaran respon spektrum adalah tanah lunak yang ada di Kabupaten/Kota di Provinsi Riau .

c. Analisis beban gempa dengan menggunakan SNI 1726-2012.

d. Bangunan yang menjadi tinjauan adalah bangunan pertokoan (café) 6 lantai.

e. Struktur bangunan yang digunakan adalah struktur beton.

Suatu bangunan direncanakan untuk dapat memenuhi segala kebutuhan fungsinya sehingga dapat menunjang kegiatan di dalamnya, seperti bangunan perkantoran yang lengkap dengan ruang pimpinan, staf, ruang meeting dan sebagainya ataupun bangunan pusat pendidikan yang lengkap dengan laboratorium, ruang belajar, ruang pertemuan dan sebagainya. Kebutuhan akan ruangan tersebut terkadang bertolak belakang dengan ketersediaan lahan dalam pembangunannya, sehingga para ahli konstruksi mulai mengembangkan bangunan bertingkat (arah vertikal) untuk memenuhi kebutuhan ruangan dengan keterbatasan lahan yang ada. Opsi ekspansi pembangunan kearah vertikal juga memiliki kepopuleran tersendiri pada satuan daerah perencanaan tertentu. Alternatif ini diajukan untuk menahan laju konversi lahan, khususnya yang berfungsi strategis sebagai penyangga kelangsungan alamiah maupun yang berperan sebagai penentu tersedianya kebutuhan dasar manusia (Suartika, 2010).

Bangunan bertingkat tinggi akan memiliki struktur gedung yang lebih kompleks demi menjamin kekuatan gedung dan keselamatan pengguna bangunan tersebut. Perkembangan ilmu rekayasa dalam bidang konstruksi saat ini sudah memungkinkan untuk menciptakan sesuatu yang dulunya mustahil termasuk dengan bangunan bertingkat tinggi.

Bangunan bertingkat tinggi akan memiliki struktur gedung yang lebih kompleks demi menjamin kekuatan gedung dan keselamatan pengguna bangunan tersebut. Perkembangan ilmu rekayasa dalam bidang konstruksi saat ini sudah memungkinkan untuk menciptakan sesuatu yang dulunya mustahil termasuk dengan bangunan bertingkat tinggi. Sehingga dengan perkembangan ilmu saat ini semua bangunan dengan bentuk gedung maupun dengan ketinggian yang tinggi bisa diwujudkan.

Menurut Suartika (2010), bangunan tinggi membutuhkan power energy untuk menggerakkan trasportasi vertikalnya, untuk pengkondisian ruangan, untuk pencahayaan, untuk operasional utilitas gedung, termasuk kemanan akan bahaya kebakaran, gempa bumi, dan lain-lain.

\section{Gempa Bumi}

Gempa bumi merupakan getaran yang bersifat alamiah, yang terjadi pada lokasi tertentu dan sifatnya tidak berkelanjutan yang disebabkan oleh pergerakan kerak bumi (lempeng bumi) secara tiba-tiba karena adanya sumber gaya sebagai penyebabnya baik bersumber dari alam maupun dari buatan manusia.

Para ahli mempelajari berbagai macam gempa yang terekam kemudian diolah sehingga menghasilkan peta gempa Indonesia, setiap daerah akan memiliki nilai gempa yang berbeda tergantung dari pergerakan batuan.

Beberapa musibah gempa yang pernah terjadi di Indonesia antara lain, 26 
Desember 2004 di Aceh 9,3 SR yang disertai dengan Tsunami, 27 Mei 2006 di Yogyakarta 5,9 SR, 30 September 2009 di Padang 7,6 SR. Adanya peristiwa gempagempa tersebut sebagai bukti bahwa Indonesia berada pada ring of fire(cincin api), seperti ditunjukkan Gambar 1.

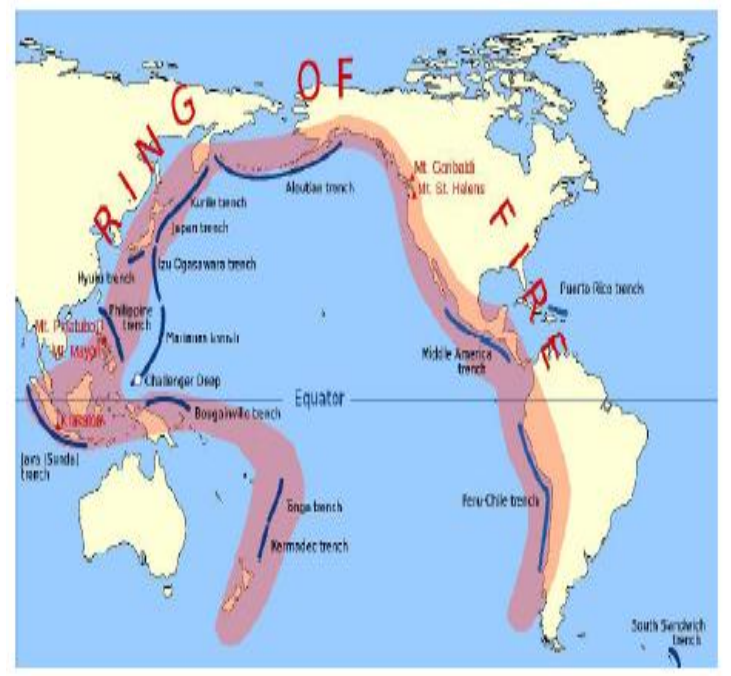

Gambar 1. Peta Ring of Fire (cincin api) (sumber:https://endrosambodo1984.wordpress. com,2016)

Sebagian besar gempa bumi disebabkan dari pelepasan energi yang dihasilkan oleh tekanan yang dilakukan oleh lempengan yang bergerak. Tekanan tersebut semakin lama akan semakin membesar hingga akhirnya mencapai keadaan tidak dapat ditahan lagi oleh pinggiran lempeng sehingga terjadilah gempa bumi. Selain itu gempa bumi juga disebabkan oleh pergerakan magma di dalam gunung berapi sebagai indikasi akan terjadinya letusan gunung berapi.

Akibat yang ditimbulkan oleh gempa berupa kerusakan bangunan dan korban jiwa yang seharusnya bisa diminimalisir dengan perencanaan bangunan tahan gempa yang tepat. Perencanaan bangunan daerah rawan gempa yang sering diaplikasikan saat ini adalah performance based seismic design berupa pemanfaatan teknik analisis non-linear dengan aplikasi komputer sehingga dengan mudah didapatkan intensitas pergerakan tanah, kemudian bisa memprediksi kondisi kritis bangunan saat terjadi gempa dan memberikan perkuatan pada kondisi kritis tersebut.

\section{Pembebanan}

Pemodelan gedung yang akan menjadi tinjauan menggunakan aplikasi software elemen hingga. Menurut Peraturan Pembebanan Indonesia untuk Gedung (PPIUG) tahun 1983 klasifikasi pembebanan adalah sebagai berikut :

a. Beban Mati

Beban mati adalah berat dari semua bagian dari suatu gedung yang bersifat tetap, termasuk segala unsur tambahan, penyelesaian-penyelesaian, mesinmesin serta peralatan tetap yang merupakan bagian yang tak terpisahkan dari gedung itu.

b. Beban hidup adalah beban yang bergerak diatas bangunan berupa manusia yang bekerja dan berbagai peralatan yang bisa dipindah-pindah. Beban hidup nominal yang bekerja pada struktur gedung adalah beban yang terjadi akibat dari aktifitas penghuni bangunan tersebut.

c. Beban Angin

Beban angin adalah beban yang diakibatkan oleh pergerakan udara dalam waktu tertentu yang dibedakan menjadi angin tekan dan angin hisap.Beban angin ditentukan oleh bentuk geometris, tinggi, kemiringan atap dan lokasi bangunan.

d. Beban Gempa

Beban gempa merupakan semua beban static ekuivalen yang bekerja pada gedung atau bagian gedung yang menirukan pengaruh dari gerakan gempa.

\section{Tanah Lunak}

Tanah terdiri dari tiga komponen yaitu udara, air dan bahan padat. Perencanan suatu bangunan perlu memperhatikan tentang kondisi tanah pada lokasi. Kementerian PU telah menyusun penyebaran pergerakan tanah dengan respon spektrum yang ada diseluruh 
Indonesia, terdiri dari batuan, tanah keras, tanah sedang dan tanah lunak. Data tersebut dapat digunakan untuk melakukan analisis beban gempa. Penurunan pondasi sering terjadi karena tidak dilakukannya penyelidikan terhadap kondisi tanah. Menurut Zaika dan Kombino (2010), proses penurunan pondasi diakibatkan oleh terkompresinya lapisan tanah di bawah pondasi akibat beban struktur. Menjadi perhatian khusus adalah tanah lunak yang memiliki daya dukung tanah yang tidak baik.

Menurut Tjandrawibawa (2002), bangunan di atas tanah lunak sering menggunakan lapisan sirtu pada bawah pondasi dangkal yang dapat meningkatkan daya dukung pondasi dengan batasan tertentu. Selain itu kondisi tanah juga akan mempengaruhi kinerja struktur pada bangunan terutama ketika terjadinya gempa yang mengakibatkan terjadinya beban horizontal tambahan.

\section{Peak Ground Acceleration (PGA)}

Percepatan adalah parameter yang menyatakan perubahan kecepatan mulai dari keadaan diam sampai terjadinya pergerakan dengan kecepatan tertentu. PGA di Indonesia lebih dikenal sebagai percepatan getaran tanah maksimum yang merupakan nilai percepatan getaran tanah yang pernah terjadi pada suatu lokasi yang diakibatkan oleh terjadinya geombang muka bumi. Besaran nilai percepatan tanah ditentukan berdasarkan magnitudo dan jarak sumber gempa yang pernah terjadi serta nilai periode dominan tanah daerah tersebut.

Menurut Febriani (2015), PGA merupakan parameter yang digunakan untuk mengetahui tingkat kerentanan suatu daerah yang diakibatkan oleh gempa bumi yang terbesar yang pernah terjadi disekitar daerah tersebut. Saat terjadinya gempa bumi akan memberikan efek terjadinya pergeseran atau perpindahan pada permukaan tanah. Percepatan gelombang yang sampai dipermukaan tanah disebabkan oleh terjadinya gempa disebut sebagai percepatan tanah.

Percepatan tanah yang digunakan untuk perhitungan strukur gedung adalah percepatan tanah maksimum sebagai efek paling parah yang terjadi pada suatu lokasi. Percepatan getaran tanah maksimum adalah nilai percepatan tanah yang terbesar yang pernah terjadi pada suatu tempat yang diakibatkan oleh gempa bumi. Menurut Purwanti (2016) Semakin besar nilai PGA yang pernah terjadi pada suatu daerah maka akan semakin besar bahaya dan resiko gempa bumi yang mungkin akan terjadi.

Melalui Kementerian PU pemerintah telah menyusun peta lokasi gempa berdasarkan nilai PGA pada setiap daerah yang ada di Indonesia yaitu pada website www.puskim.pu.go.id. Besaran PGA tersebut bisa digunakan sebagai nilai parameter dalam melakukan perhitungan struktur gedung.

\section{Respons Spektrum}

Respon spektrum merupakan suatu spektrum yang disajikan dalam bentuk grafik/plot antara periode getar struktur (T) berdasarkan respon-respon rasio redaman dan gempa tertentu. Respon spektrum disain untuk perencanaan gedung ditentukan berdasarkan wilayah gempa Indonesia dengan percepatan puncak batuan dasar dengan periode ulang 500 tahun. Respon Spektrum tersebut dinyatakan dengan grafik C-T dengan $\mathrm{C}$ adalah factor respon gempa dalam $\mathrm{g}$ dan $\mathrm{T}$ adalah waktu getar alami struktur dalam detik. Nilai koefisien gempa dasar $\mathrm{C}$ pada respon spektrum harus dikalikan dengan factor koreksi I/R, dimana I adalah faktor keutamaan dan $\mathrm{R}$ adalah faktor reduksi gempa.

Sebagian besar gempa bumi disebabkan dari pelepasan energi yang dihasilkan oleh tekanan yang dilakukan oleh lempengan yang bergerak. Tekanan tersebut semakin lama akan semakin membesar hingga akhirnya mencapai keadaan tidak dapat ditahan lagi oleh pinggiran lempeng. Sehingga terjadilah 
gempa bumi. Selain itu gempa bumi juga disebabkan oleh pergerakan magma di dalam gunung berapi sebagai indikasi akan terjadinya letusan gunung berapi.

\section{Kinerja Struktur}

Analisis respon diagram merupakan analisis struktur linear dinamik untuk memperoleh respon struktur maksimum yang telah memperhitungkan kontribusi ragam getar alamai struktur yang lebih tinggi. Analisis ragam yang digunakan yaitu displacement, accelearatiaon dan shear story.

Berdasarkan SNI Gempa 03-17262002 disebutkan bahwa jumlah ragam vibrasi yang ditinjau dalam penjumlahan respon harus menghasilkan partisipasi massa minimum 90\% sehingga sebelum melakukan analisis respon spektrum perlu dilakukan analisis respon ragam.

\section{Kinerja Batas Layan}

Menurut Haryanto (2011), kinerja batas layan struktur gedung ditentukan oleh simpangan antar tingkat akibat pengaruh gempa rencana, yaitu untuk membatasi terjadinya pelelehan baja dan peretakan beton yang berlebihan disamping untuk mencegah kerusakan nonstruktur dan ketidaknyamanan penghuni.

Berdasarkan SNI 1726-2012 mensyaratkan bahwa simpangan antar tingkat yang didapatkan dari simpangan struktur gedung tidak boleh melampaui $\frac{0,03}{R} x$, dimana :

$$
\begin{array}{ll}
\mathrm{R} & =\text { koefisien modiikasi respon } \\
\mathrm{H} & =\text { tinggi tingkat }
\end{array}
$$

\section{Kinerja Batas Ultimit}

Menurut Wibowo (2011), kinerja ultimit gedung ditentukan oleh simpangansimpangan antar tingkat maksimum struktur gedung akibat pengaruh gempa rencana dalam kondisi struktur gedung diambang keruntuhan yaitu untuk membatasi kemungkinan terjadinya keruntuhan struktur gedung yang dapat menimbulkan korban jiwa manusia dan untuk mencegah benturan berbahaya antar gedung atau antar bagian struktur gedung yang dipisah dengan sela pemisah (selade latasi).

\section{Kerusakan Bangunan}

Akibat adanya gempa seringkali mengakibatkan terjadinya kerusakan pada bangunan.Kerusakan tersebut sangat bervarisi mulai dari kerusakan non struktur sampai pada kerusakan pada elemen struktur bangunan gedung sehingga diperlukan perencanaan yang baik untuk menghindari terjadinya kerusakan maupun korban jiwa. Menurut Sukamta (2006), untuk bangunan rumah tingal tembokan sederhana kunci tahan gempa pertama adalah pemakaian balok pondasi (sloof), kolom praktis dan ring balok yang dibuat dari beton bertulang dan disatukan dengan pasangan batanya.

Kunci kedua adalah dengan memakai atap yang relatif ringan dan terikat dengan baik pada konstruksi atapnya.Untuk gedung-gedung konstruksi beton kunci keberhasilannya dalam menahan gempa terletak pada dua hal yaitu menaruh kait sengkang yang cukup dengan ujung yang cukup panjang dan ditekuk $135^{\circ}$ dan membuat tiang kolom beton lebih kuat daripada baloknya. Secara umum kerusakan bangunan yang terjadi akibat gempa beraneka ragam, tergantung pada skala kekuatan gempa itu sendiri

\section{METODOLOGI}

Analisis dilakukan dengan menggunakan software elemen hingga dan mengacu pada SNI 03-1726-2012. Model sruktur didesain 6 lantai dan menggunakan struktur beton bertulang.

Dimensi struktur gedung pertokoan (cafe) secara keseluruhan adalah sebagai berikut :

1. Balok

Dimensi balok yang digunakan bervariasi antara lain $300 \times 600 \mathrm{~mm}$, $300 \times 500 \mathrm{~mm}, 250 \times 500 \mathrm{~mm}, 200 \times$ $400 \mathrm{~mm}, 150 \times 600 \mathrm{~mm}$. 
2. Kolom

Dimensi kolom yang digunakan pada gedung ini antara lain $450 \times 450 \mathrm{~mm}$, $400 \times 400 \mathrm{~mm}$, dan $200 \times 400 \mathrm{~mm}$.

3. Pelat lantai

Ketebalan pelat lantai yang digunakan seragam yaitu $120 \mathrm{~mm}$.

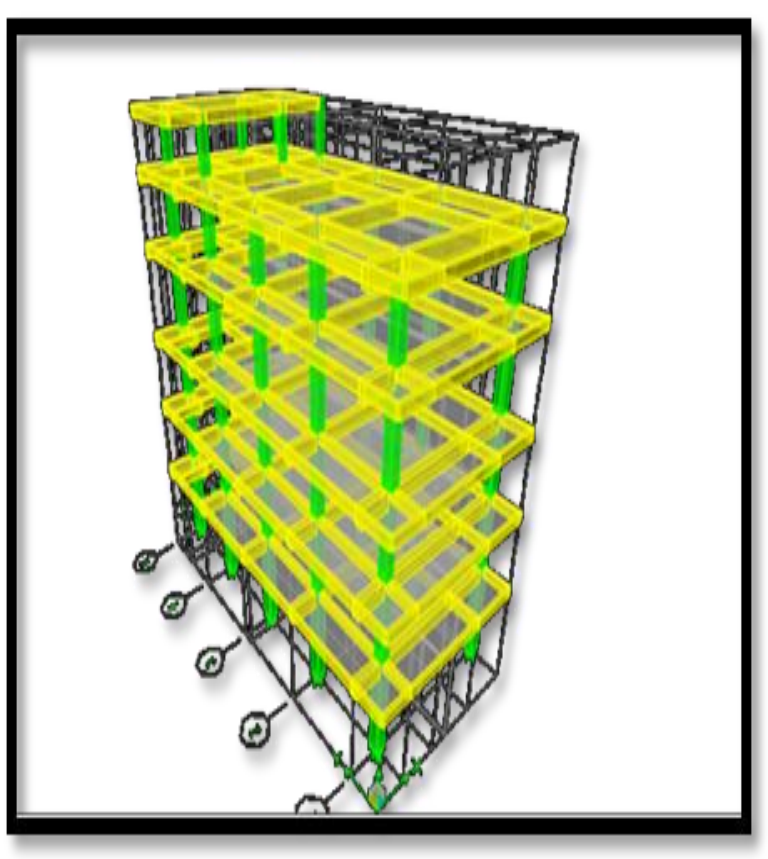

Gambar 2. Pemodelan Struktur

Output dari hasil analisis software yang digunakan sebagai pembanding adalah nilai base shear. Respons spektrum yang digunakan adalah kondisi tanah lunak pada seluruh Kabupaten/Kota di Riau. Respons Spektrum tersebut dapat digambarkan menjadi diagram yang menunjukkan hubungan antara perioda waktu (t) dengan pada masing-masing daerah.

Pengambilan jenis tanah lunak sebagai lokasi objek penelitian adalah tanah lunak merupakan tanah dengan daya dukung paling rendah jika dibandingkan dengan jenis tanah lainnya.

Selain itu tanah lunak untuk kasuskasus tertentu perlu dilakukan penguatan dengan metoe khusus untuk mendapatkan daya dukung yang memenuhi syarat untuk struktur bangunan.

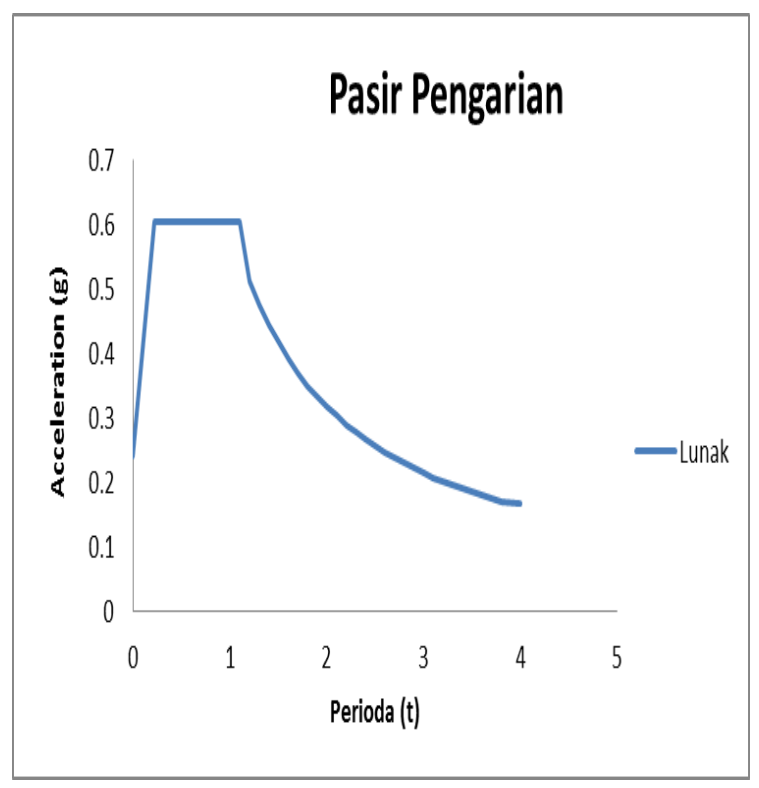

Gambar 3. menunjukkan koefisien gempa elastik struktur sebagai fungsi dari perioda struktur kabupaten Indragiri hilir (Tembilahan). Sementara untuk berbagai kabupaten/kota lainnya yang dianalisis akan memiliki grafik respon spektrum tanah yang berbeda. Hal ini disebabkan masingmasing kabupaten/kota memiliki tingkat resiko gempa yang berbeda.

Analisa elemen hingga dilakukan dengan bantuan software elemen hingga untuk memodelkan seluruh komponen. Langkah-langkah analisis rspon spektrum adalah sebagai berikut :

1. Memodelkan elemen struktur bangunan dengan mendefenisikan terlebih dahulu material dan dimensi elemen struktur beserta dengan pembebanannya.

2. Melakukan analisis ragam hingga partisipasi massa ragam komulatif sudah melebihi 90\%. Kemudian lakukan pendefenisian fungsi respon spektrum $\left(c_{s m}\right.$ vs $\left.T\right)$ berdasarkan grafik respon spektrum untuk tanah lunak kabupaten/kota yang ada di Riau.

3. Melakukan analisis respon spektrum untuk mendapatkan keluaran berupa respon struktur diantaranya perpindahan (displacement) dalam satuan meter, percepatan (drift story) dalam satuan meter/detik dan gaya geser (shear story) dalam satuan kilogram 


\section{HASIL DAN PEMBAHASAN}

\section{Hasil Respon Diagram}

Analisis ragam dilakukan hingga ragam ke-12 dengan partisipasi massa ragam mencapai angka 99,545 pada arah $X$ dan 99,12 pada arah Y. Berdasarkan data tersebut maka partisipasi massa ragam telah memenuhi persyaratan yang menyatakan bahwa partisapasi ragam harus melebihi 90\%. Partisipasi massa ragam komulatif dapat dilihat pada Gambar 4. Sedangkan hasil analisis respon spektrum yang ditinjau adalah displacement (perpindahan), acceleration (perpindahan) dan gaya geser (shear story) pada setiap lantai bangunan bertingkat.

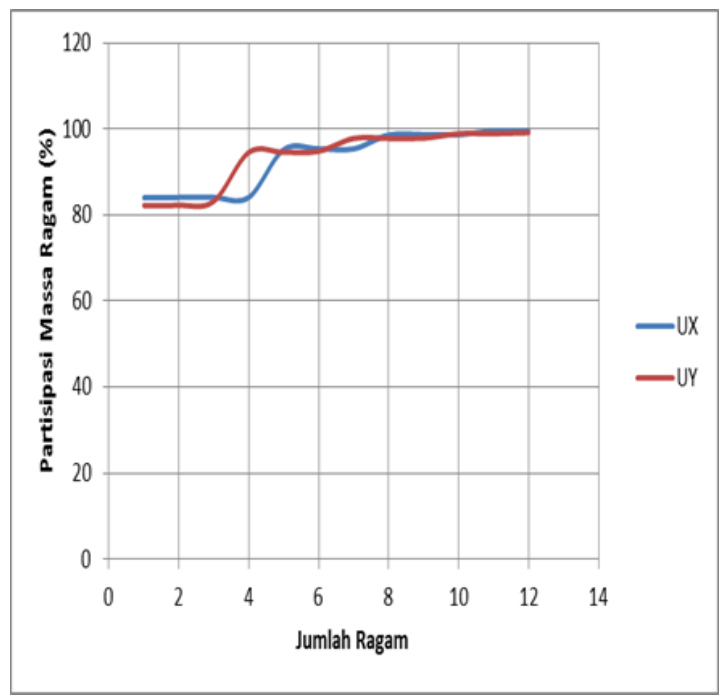

Gambar 4. Partisipasi massa diagram

\section{Hasil Analisis story shear}

Hasil analisis base shear yang terjadi pada bangunan bertingkat di semua Kabupaten / Kota di Riau seperti ditinjukkan pada Gambar 5 dan Gambar 6.

Analisis dilakukan dengan menggunakan software elemen hingga pada setiap lantai bangunan yang ditinjau dan pada setiap Kabupaten / Kota yang ada di Provinsi Riau dengan tinjauannya terhadap tanah lunak yang sering memiliki daya dukung yang lebih rendah sehingga untuk perhitungan struktur mesti dilakukan dengan teliti.

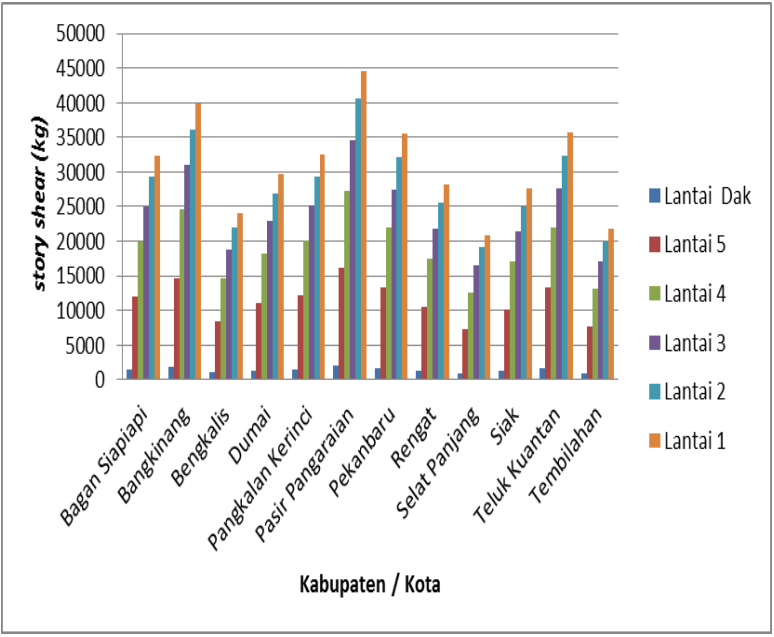

Gambar 5. story shear arah X

Berdasarkan Gambar 4 nilai story shear arah $\mathrm{X}$ maksimum untuk kondisi tanah lunak terjadi pada kabupaten Rokan Hulu (pasir pengaraian) dengan besaran $44540,05 \mathrm{~kg}$ pada lantai 1 , sedangkan kondisi paling rendah adalah Kabupaten Meranti (Selat panjang) dengan besaran $869,35 \mathrm{~kg}$ pada Lantai dak.

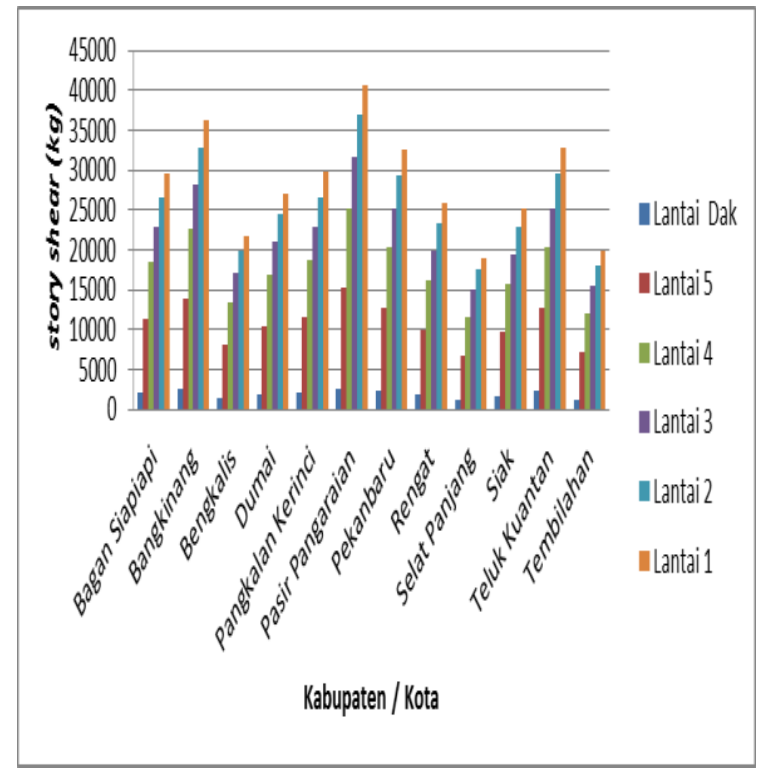

Gambar 6. story shear arah Y

Berdasarkan Gambar 6. nilai story shear arah Y maksimum untuk kondisi tanah lunak terjadi pada kabupaten Rokan Hulu (pasir pengaraian) dengan besaran $40.569,96 \mathrm{~kg}$ pada lantai 1 , sedangkan kondisi paling rendah adalah Kabupaten Meranti (Selat Panjang) dengan besaran $10.54,53 \mathrm{~kg}$ pada Lantai dak. 
Tabel 1. Hubungan story shear dengan PGA

\begin{tabular}{llccc}
\hline No & Kabupaten/Kota & $\begin{array}{c}\text { Story shear } \mathbf{X} \\
(\mathbf{K g})\end{array}$ & $\begin{array}{c}\text { Story shear } \mathbf{Y} \\
(\mathbf{K g})\end{array}$ & PGA $(\mathbf{g})$ \\
\hline $\mathbf{1}$ & Pasir pengaraian & $44.540,05$ & $40.569,96$ & 0,317 \\
$\mathbf{2}$ & Bangkinang & $39.906,02$ & $36.356,84$ & 0,248 \\
$\mathbf{3}$ & Teluk Kuantan & $35.718,69$ & 32699,86 & 0,214 \\
$\mathbf{4}$ & Pekanbaru & $35.623,14$ & $32.596,04$ & 0,213 \\
$\mathbf{5}$ & Pangkalan kerinci & $32.552,49$ & $29.686,4$ & 0,192 \\
$\mathbf{6}$ & Bagan siapiapi & $32.377,12$ & $29.522,13$ & 0,169 \\
$\mathbf{7}$ & Dumai & $29.691,54$ & $27.096,64$ & 0,146 \\
$\mathbf{8}$ & Rengat & $28.241,46$ & $25.808,13$ & 0,131 \\
$\mathbf{9}$ & Siak & $27.623,16$ & $25.229,55$ & 0,127 \\
$\mathbf{1 0}$ & Bengkalis & $23.966,86$ & $21.824,41$ & 0,091 \\
$\mathbf{1 1}$ & Tembilahan & $21.769,87$ & $19.752,11$ & 0,080 \\
$\mathbf{1 2}$ & Selat Panjang & $20.929,13$ & $18.993,35$ & 0,067 \\
\hline
\end{tabular}

Gambaran pola hubungan antara besaran nilai PGA dengan shear pada masing-masing Kabupaten/Kota yang ada di Riau seperti ditunjukkan oleh Gambar 7.

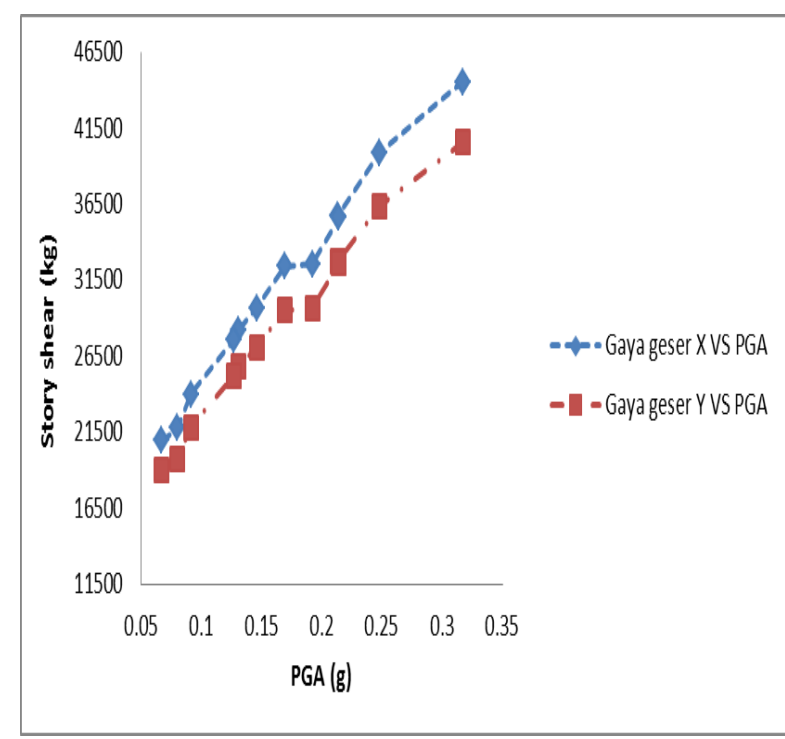

Gambar 7. Hubungan antara nilai PGA dengan Story shear

Berdasarkan Gambar 7 dapat dijelaskan bahwa semakin tinggi nilai PGA maka semakin tinggi pula Story shear yang terjadi. Hubungannya bersifat linear. Pengujian tingkat kevalitan dari hubungan PGA dan Story shear seperti ditunjukkan Gambar 8. Dimana pengukuran hubungan korelasi berdasarkan koefisein korelasi, yaitu pengukuran statistik kovarian atau asosiasi antara dua variable. Untuk memudahkan dalam melakukan interpretasi mengenai kekutan hubungan antara dua variable dibuat kriteria sebagai berikut :

$\begin{array}{ll}\mathrm{R}=0 & \text { : Tidak ada korelasi } \\ 0<\mathrm{R} \leq 0,25 & \text { : Sangat lemah } \\ 0,26<\mathrm{R} \leq 0,50 & : \text { Sangat cukup } \\ 0,51<\mathrm{R} \leq 0,75 & \text { : Kuat } \\ 0,76<\mathrm{R} \leq 0,99 & \text { : Sangat kuat } \\ \mathrm{R}=1 & \text { : Sempurna }\end{array}$

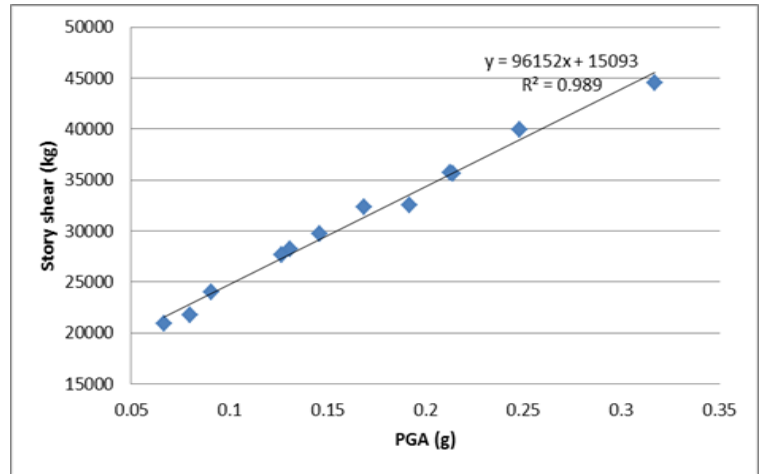

Gambar 8 Grafik Regresi Story shear 
Berdasarkan grafik regresi Story shear arah $\mathrm{X}$ maka didapatkan regresi $\mathrm{y}=$ $96152 \mathrm{x}+15093$ dan $\mathrm{R}^{2}=0,989$ menunjukkan bahwa korelasi PGA terhadap Story shear sangat kuat karna salah satu indikasinya adalah nilai $\mathrm{R}$ mendekati 1 .

Story shear yang terjadi pada semua Kabupaten/kota yang ada di Provinsi Riau terjadi pada lantai 1 yang terletak diatas permukaan sehinnga saat terjadinya gaya horizontal getaran yang terjadi terbesar terjadi pada lantai 1 , berbeda dengan lantai puncak bangunan gedung gaya geser yang terjadi relatif lebih kecil karena telah tereduksi oleh lantai yang ada di bawahnya.

Reduksi beban horizontal (beban gempa) pada bangunan bertingkat perlu dilakukan penambahan elemen struktur yaitu dengan dinding geser (shear wall) karena dinding geser mampu memperkaku elemen struktur agar bangunan tetap stabil sehingga tidak terjadi kerusakan pada bangunan.

\section{SIMPULAN}

Hasil analisis yang didapatkan dengan menggunakan software elemen hingga, adalah sebagai berikut :

1. Semakin tinggi besaran nilai (Peak Groun Acceleration) PGA maka akan semakin tinggi reaksi story shear.

2. Lantai yang mendapat efek tertinggi dari . story shear adalah lantai dasar (base) karena bagian lantai dasar merupakan bagian yang berhubungan langsung dengan tanah yang dapat meneruskan gaya horizontal (gempa).

3. Kota Pasir Pangaraian menjadi kota dengan nilai hasil analisis respon spektrum dan nilai PGA tertinggi karena Kota Pasir Pangaraian merupakan kota paling dekat dengan Provinsi Sumatera Barat yang memiliki intensitas gempa cukup tinggi sehingga akan ikut mempengaruhi kondisi pergerakan tanah, sedangkan Kota Selat Panjang merupakan daerah dengan besaran nilai PGA paling rendah karena jauh dari sumber gempa.

\section{SARAN}

Hasil analisis yang dilakukan menunjukkan pengaruh respon spektrum terhadap story shear maka penulis memiliki beberapa saran untuk dilakukan penelitian lanjutan, antara lain :

1. Analisis dengan metode respon spektrum bisa dilakukan pada kondisi tanah sedang dan keras serta untuk daerah dengan intensitas gempa yang tinggi..

2. Selain terhadap nilai percepatan tanah puncak (PGA) kedepan bisa dilakukan analisis terhadap nilai Periode pendek (Ss) dan Periode 1 detik (S1).

\section{DAFTAR PUSTAKA}

Faizah, R. (2013). Analisa Gaya Gempa Rencana Pada Struktur Bertingkat Banyak Dengan Metode Dinamik Respon Spektra, 7(KoNTekS 7), 24-26.

Febriani, Y. (2015b). Analisis Percepatan Getaran Tanah Maksimum di Wilayah Kabupaten Rokan Hulu Akibat Gempa Bumi Sumatera Barat, 4(2), 135-138.

Firdaus, W. (2010). Prediksi Perilaku Pelat Beton Di Atas Tanah Lunak Menggunakan Metode Boef ( Beams On Elastic Foundation ) Ditinjau Pada Variasi Tebal Pelat Beton Dan Nilai Pembebanan. Surakarta: Universitas Sebelas Maret.

Hariyanto, A. (2011). Analisis Kinerja Struktur pada Bangunan Bertingkat

Tidak Beraturan Dengan Analisis Dinamik Menggunakan Analisis Respon Spektrum. Surakarta: Univeristas Sebelas Maret.

Kasuma, W. (2009). Identifikasi Kegagalan, Alternatif Perbaikan dan Perkuatan pada Struktur Gedung Poltekes Siteba Padang. 
Pirwanti, A. (2016). Analisa Tingkat Resiko Dari Nilai Peak Ground Acceleration (PGA) Berdasarkan Data Mikroseismik Disekitar jalur Sesar Opak Kabupaten Bantul Yogyakarta. Yogyakarta: UIN Sunan Kalijaga.

Suartika, G. A. M. (2010). Pengaturan batas ketinggian bangunan dalam menjaga keberlanjutan bentang alam dan lingkungan terbangun, 146-158.

Suharyanto. (2013). Rekayasa Gempa. Universitas Janabrada, Yogyakarta.

Wibowo, A. S. (2011). Analisis Kinerja Struktur Pada Bangunan Bertingkat Tidak Beraturan Dengan Analisis Dinamik Menggunakan Metode Analisis Riwayat Waktu.

Wisnumurti, I. C. dan A. A. (2013). Analisis Pushover Pada Gedung Tidak Beraturan Dengan Study Kasus Pada Gedung Baru FIA UNIBRAW. Journal of Chemical Information and Modeling, 53(9), 1689-1699.

http://doi.org/10.1017/CBO9781107 415324.004 